Vol. 1, $\mathcal{N}$ o.1, Agustus 2018 | P-ISSN: 2622-9862 |E-ISSN: 2622-707X

\title{
PENERAPAN MODEL PEMBELAJARAN THINK TALK WRITE PADA MATA PELAJARAN PENDIDIKAN KEWARGANEGARAAN UNTUK MENINGKATKAN HASIL BELAJAR SISWA
}

\author{
Lina Marlina ${ }^{1}$, Ade Millatus Sa'diyah ${ }^{2}$, Fajar Mauludin ${ }^{3}$ \\ Universitas Banten Jaya \\ Serang, Indonesia \\ linamarlina@unbaja.ac.id ${ }^{1}$, Ade.Millatus@ gmail.com² , Fajar.abdulhamid@gmail.com
}

\begin{abstract}
This research is motivated by the reality of the field when making initial observations that menunyarat that students are considered less active, less attention to the lessons described by teachers. One of the goals of this research is to improve the learning process by using Think Talk Write learning model which aims to improve student learning outcomes. The research design is done through two cycles, starting from planning, execution, observation, reflection, and continuing with next cycle planning. Classroom Action Research took place from January 12, 2017 to March 42017 by using data collection tools from test results and learning outcomes learning instruments. Students' learning outcomes in each cycle experienced an increase evidenced from the results of the cycle I $73 \%$ and $86 \%$ cycle II. Reinforced by the average of pretest result in cycle 1 is 54,16 while for result of postest for cycle I is 71,25, mean that in cycle I mean result of student learning up $17,09 \%$, while for postest cycle II average 80.4 means that in cycle II the average of student learning outcomes up $9.15 \%$. Based on the data, if the average pretest of cycle I is 54,16 and posttest result of cycle II 80,4 then the average increase of student learning result from pretest cycle I until post cycle II is 26,24\%. Thus it can be concluded that using the Think Talk Write (TTW) model can improve student learning outcomes. So it is recommended for teachers related to education to apply and develop the Think Talk Write (TTW) learning model as an alternative in improving student learning outcomes.
\end{abstract}

Keywords: Think Talk Write Learning Model, Civic Education Learning, Student Learning Outcomes.

\section{PENDAHULUAN}

Guru diharapkan mampu lebih mengembangkan profesionalisme dalam membelajarkan siswa dalam fungsinya sebagai fasilitator pembelajaran.Terdapat banyak teori pembelajaran yang dikembangkan para ahli dalam upaya memberikan masukan serta pengetahuan bagi para guru yang bertujuan untuk menjadikan siswa didikannya unggul dan menjadi jaminan bagi masa depan siswa itu sendiri baik yang akan melanjutkan pendidikannya atau yang akan terjun ke masyarakat.
Untuk mengetahui definisi pendidikan dalam perspektif kebijakan, kita telah memiliki rumusan Formal dan Operasional, sebagaimana terbentuk dalam UU No. 20 Tahun 2003 tentang SISDIKNAS, yaitu: Pendidikan adalah usaha sadar dan terencana untuk mewujudkan suasana belajar dan proses pembelajaran agar peserta didik secara aktif mengembangkan potensi dirinya untuk memiliki kekuatan spiritual keagamaan, pengendalian diri, kepribadian, kecerdasan, akhlak mulia, serta keterampilan yang di perlukan diriya, masyarakat, bangsa dan negara. 
Dalam konteks pembelajaran yang di lakukan guru, maka guru di tuntut untuk dapat mengelola pembelajaran (learning management), dalam definisi pendidikan yang tertuang dalam UU No. 20 Tahun 2003, tampaknya tidak hanya sekedar menggambarkan apa pendidikan iti, tetapi memiliki makna dan implikasi yang luas tentang siapa sesungguhnya pendidik itu, siapa peserta didik itu, bagaimana seharusnya mendidik, dan apa yang ingin di capai oleh pendidikan.

Belajar adalah suatu proses usaha yang di lakukan seseorang untuk memperoleh perubahan tingkah laku yang baru secara keseluruhan sebagai hasil pengalamannya sendiri dalam interaksi dengan lingkungannya (Slameto, 2003: 2). Perubahan itu bersifat relatif konstan dan berbekas.

Dalam kaitan ini, proses belajar dan perubahan merupakan bukti hasil yang di proses. Belajar tidak hanya mempelajari mata pelajara, tetapi juga penyusunan, kebiasaan, persepsi, kesenangan atau minat, penyesuaian sosial, bermacam-macam keterampilan lain, dan cita-cita (Hamalik, 2002:45). Dengan demikian, seseorang di katakan belajar apabila terjadi perubahan pada dirinya akibat adanya latihan dan pengalaman melalui interaksi dengan lingkungan.

Belajar siswa berkaitan dengan hasil belajarnya, dalam hal ini hubungan antar siswa di kelas harus terjalin dengan baik. Oleh karena itu, guru perlu melakukan tindakan pengkondisian dimana siswa dapat melakukan kerja sama dalam kelompok yang lebih kecil dan salah satu strateginya adalah dengan pembelajaran berkelompok atau kooperatif, misalnya dengan pemberian tugas dan kerja kelompok.

Pembelajaran dilakukan dengan cara meningkatkan aktivitas bersama sejumlah siswa dalam satu kelompok. Aktivitas pembelajaran kooperatif menekankan pada kesadaran siswa untuk saling membantu dan mengolah informasi, mengaplikasikan pengetahuan dan keterampilan. Pembelajaran dapat dikatakan berhasil jika siswa dapat mencapai tujuan mereka dengan saling membantu. (Abdullah Sani, 2013, hlm. 131-132)

Untuk itu, pembelajaran yang berpusat pada siswa sangat disarankan dilakukan para guru dalam proses pembelajaran di kelas. Mengingat proses belajar siswa yang tergantung hasil belajar seperti yang telah diuraikan, maka penulis merasa perlu untuk memilih metode pembelajaran yang mencakup keduanya yaitu pembelajaran yang bersifat kooperatif dan pembelajaran yang berpusat pada siswa serta mampu mengkonstruksi pengetahuan konsep siswa.

Berdasarkan pengamatan sementara 
yang saya lakukan di kelas XI IPS 1 MA Masyariqul Anwar Caringin dalam pelaksanaan pembelajaran di kelas dalam mata pelajaran PPKn masih jauh dari yang di harapkan, tidak terjadinya komunikasi dengan baik antara pendidik dan peserta didik, sehingga hal in sangat berpengaruh terhadap hasil belajar peserta didik yang pada saat di lakukannya test itu masih banyak yang mendapatkan nilai dibawah rata-rata. Mungkin karna system belajar yang masih terlalu monoton yang di lakukan oleh pendidik pada saat menyampaikan materi dikelas, sehingga peserta didikpun merasakan jenuh, tidak konsen, mengantuk, dan sebagainya.

Berdasarkan masalah di atas, dapat simpulkan bahwa hasil belajar siswa dalam proses pembelajaran PKn cenderung rendah. Untuk itu, melalui penelitian ini penulis berusaha untuk memperbaiki hasil belajar siswa dalam proses pembelajaran. Dari permasalahan diketahui bahwa siswa kurang aktif, kurang memperhatikan pelajaran yang dijelaskan guru, lamban dalam menjawab apayang ditanyakan guru, bahkan tidak terjawab dan kemampuan siswa dalam menganalisis, hal ini sangat sesuai dengan strategi yang dipilih penulis. Salah satu usaha untuk memperbaiki proses pembelajaran tersebut adalah dengan menggunakan model pembelajaran Think talk write yang bertujuan untuk meningkatkan hasil belajar siswa.

Think Talk Write (TTW) adalah strategi yang memfasilitasi latihan berbahasa lisan dan menulis bahasa tersebut dengan lancar. Strategi yang di perkenalkan pertama kali oleh Huinker dan Laughlin (1996, hlm.82). Strategi ini didasarkan pada pemahaman bahwa belajar adalah sebuah perilaku sosial. Strategi TTW mendorong siswa untuk berpikir, berbicara, dan kemudian menuliskan suatu topik tertentu. Strategi ini di gunakan untuk mengembangkan tulisan dengan lancar dan melatih bahasa sebelum di tuliskan. Strategi TTW memperkenankan siswa untuk memengaruhi dan memanipulasi ide-ide sebelum menuangkanya dalam bentuk tulisan. ia juga membantu siswa dalam mengumpulkan dan mengembangkan ideide memalui percakan terstrruktur.

Oleh sebab itu peneliti tertarik ingin melakukan suatu penelitian tindakan sebagai upaya dalam melakukan perbaikan terhadap model pembelajaran dengan judul 'Penerapan Model Pembelajaran Kooperatif Tipe think talk write (TTW) Pada Mata Pelajaran Pendidikan Kewarganegaraan (PKn) Untuk Meningkatkan Hasil Belajar Siswa."

\section{METODE PENELITIAN}

Bentuk penelitian ini adalah Penelitian 
Tindakan Kelas (PTK) atau Classroom Action Research (CAR) yang bertujuan untuk perbaikan proses pembelajaran, memecahkan masalah yang timbul di dalam kelas ketika pembelajaran berlangsung, dan meningkatkan kualitas proses maupun hasil pembelajaran di kelas.

Penelitian di lakukan di sekolah di kelas XI IPS 1 MA Masyariqul Anwar Caringin. Penelitian dilaksanakan di kelas kelas XI IPS 1 MA Masyariqul Anwar Caringin ahun pelajaran 2016 - 2017. Mulai dari 12 Januari sampai dengan 4 Maret.

Subyek penelitian di kelas kelas XI IPS 1 MA Masyariqul Anwar Caringintahun pelajaran 2016 - 2017. berjumlah 30 orang, terdiri dari 13 orang siswa laki - laki dan 17 orang siswa perempuan.

Alasan peneliti menggunakan model Kemmis dan MC Taggart karena metode penelitian ini lebih sederhana dan mudah dipahami oleh peneliti, dan model PTK ini terdiri dari empat tahapan yaitu perencanaan, tindakan, observasi dan refleksi.

Desain penelitian di mulai dengan pemilihan subjek kemudian, metodemetode yang berhubungan dengan pengumpulan data.

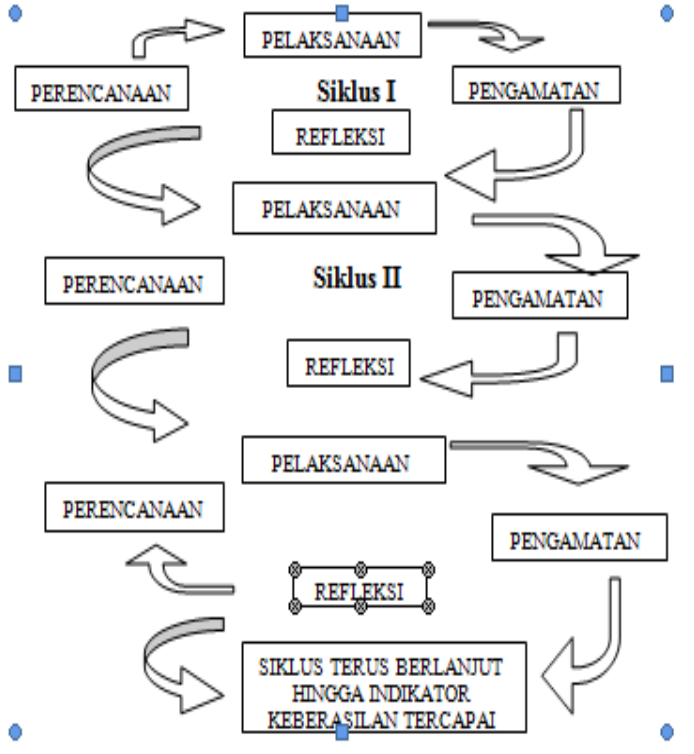

Gambar 1 Alur PTK menurut Model Gabungan Kemmis dan Mc Taggart

Dalam perencanaan pelaksanaan penelitian mencakup beberapa kegiatan antara lain:

1) Tim peneliti melakukan analisis standar isi untuk mengetahui Standar Kompetensi dan Kompetensi Dasar (SKKD) yang akan diajarkan kepada siswa.

2) Mengembangkan Rencana Pelaksanaan Pembelajaran (RPP), dengan memperhatiakan indikator-indikator hasil belajar.

3) Mengembangkan alat peraga, alat bantu atau media pembelajaran yang menunjang pembentukan SKKD dalam rangka implementasi PTK.

4) Menyusun alat evaluasi pembelajaran sesuai dengan indikator hasil belajar.

Pelaksanaan PTK mencakup prosedur dan pelaksanaan yang akan dilakukan, serta proses perbaikan yang akan dilakukan. 
Selanjutnya adalah observasi yang dilakukan sesuai dengan prosedur dalam proses dan hasil implementasi tindakan yang dilakukan. Penggunaan pedoman atau instrument hal ini juga perlu dilakukan untuk ditindaklanjuti dengan refleksi.

Berikutnya adalah tahap refleksi, tahapan ini ditunjukkan untuk menjelaskan tentang prosedur dan analisis hasil pamantauan tentang proses dan dampak tindakan perbaikan selanjutnya.

Pada perencanaan di siklus pertama ini guru sebagai peneliti membuat Rencana Pelaksanaan Pembelajaran (RPP) sesuai dengan SKKD dalam Standar Isi (SI) yang disesuaikan dengan materi ajar yang akan di laksanakan pada proses belajar mengajar.

Pada tahap pelaksanaan Peneliti melaksanakan proses pembelajaran berdasarkan RPP yang dikembangkan dari hasil refleksi siklus pertama dan akan di tindak lanjuti di siklus berikutnya.

Peneliti mengadakan observasi terhadap proses pembelajaran dan pembentukan kompetensi siswa.

Peneliti melakukan refleksi terhadap pelaksanaan siklus kedua dan menganalisis serta menarik kesimpulan terhadap pelaksaan pembelajan yang telah di rencanakan dengan melaksanakan tindakan tertentu apakan pembelajan yang di rancang dengan PTK dapat meningkatkan kualitas pembelajaran atau memperbaiki masalah.
Adapun teknik penelitian yang digunakan adalah observasi, tes, wawancara, dan dokumentasi. Dalam penelitian ini instrumen yang digunakan dalam mengukur peningkatan aktivitas belajar peserta didik adalah dengan menilai indikator-indikator dari aktivitas belajar. Adapun instrument yang digunakan adalah format observasi, tes hasil belajar, wawancara/pedoman wawancara dan dokumentasi/daftar dokumentasi.

Sebagai tolak ukur meningkatnya hasil belajar siswa pada mata pelajaran PPKn melalui model pembelajaran Think Talk Write dapat dilihat dari hasil Kriteria Ketuntasan Minimal (KKM) belajar siswa. Indikator keberhasilan siswa yang menjadi indikator utama hasil belajar siswa adalah sebagai berikut: Ketercapaian daya serap terhadap bahan pembelajaran yang di ajarakan, baik secara individual maupun kelompok.

Teknik analisis data yang peneliti lakukan disekolah yaitu dengan menggunakan tes hasil belajar peserta didik. Dimana dalam teknik ini terdapat kegiatan mencermati dan menguraikan serta mengaitkan setiap informasi yang terkait dengan kondisi awal, proses belajar dan hasil belajar untuk memperoleh kesimpulan tentang keberhasilan tindakan perbaikan pembelajaran. Berikut adalah langkah- 
langkah dalam analisis data. Reduksi Data, merupakan proses merangkum, memilih hal yang penting dan memfokuskan pada hal yang dirasa penting, dicari pola dan temanya. Selanjutnya, display data (Memaparkan data), berati menyajikan data dalam bentuk uraian singkat, bagan, hubungan antar katagori dan sebagainya. Yang terakhir adalah mengambil Kesimpulan dan Verifikasi Data, yaitu proses perumusan makna dari hasil penelitian yang dilakukan dan diungkapkan dengan kalimat yang singkat, padat dan mudah dipahami serta dilakukan dengan cara berulang kali, melakukan peninjauan mengenai kebenaran dan penyimpulan itu, khususnya berkaitan dengan relevansi dan konsistennya terhadap judul, tujuan dan perumusan masalah yang ada.

Pengolahan Tes Hasil Belajar :

$$
\begin{aligned}
& \text { NA= } \underline{\mathrm{B}} \text { X100 } \\
& \text { Keterangan : } \\
& \text { NA = Nilai Akhir } \\
& \mathrm{B}=\text { Jumlah jawaban yang benar } \\
& \mathrm{N}=\text { Jumlah soal }
\end{aligned}
$$

Tabel 1. Kriteria Nilai Hasil Belajar

\begin{tabular}{llll}
\hline & Nilai & & Kategori \\
\hline $\mathrm{A}=$ & $85-100$ & $:$ & Sangat Baik \\
$\mathrm{B}=$ & $75-84$ & $:$ & Baik \\
$\mathrm{C}=$ & $65-74$ & $:$ & Cukup \\
$\mathrm{D}=$ & $55-64$ & $:$ & Kurang
\end{tabular}

Menghitung rata-rata kelas :

Nilai rata-rata kelas

= Jumlah Nilai Akhir yang diperoleh siswa

Jumlah siswa

Dalam penelitian ini, peneliti melakukan kolaborasi bersama dengan guru kelas IPS 1 MA Masyariqul Anwar Caringin yang bernama Iis Tisnawati S.Pd. Guru sebagai pelaksana dalam kegiatan penelitian dan menerapkan model pembelajaran Think Talk Write. Peneliti sebagai perencana atau observer kegiatan pembelajaran dan mengawasi jalannya kegiatan pembelajaran.

\section{HASIL PENELITIAN DAN PEMBAHASAN}

Pada kegiatan pra siklus dilakukan melalui 1 pertemuan yaitu pada tanggal 18 januari 2017 pukul 11.30-13.15 WIB selama 2x45 Menit. Pada kegiatan ini dilakukan tanya jawab dan refleksi yang disertai dengan adanya pengambilan data tes siswa tentang pelajaran yang sudah diajarkan untuk mengetahui tentang keadaan awal penggunaan metode pembelajaran pada proses pembelajaran Pendidikan Kewarganegaan sebelum diberi tindakan melalui metode pembelajaran TTW (Think Talk Write).

Pada tanggal 01 Februari 2017 penulis memberikan pre tes yang 
bertujuan untuk mengetahui kemampuan awal siswa. Tes dimulai pukul 11.3013.15 WIB, adapun soal pre tes dapat dilihat pada lampiran. Dari data yang diperoleh banyaknya siswa yang tuntas belajar ada 11 orang siswa dan 19 orang siswa yang belum mencapai ketuntasan belajar, dengan rata-rata nilai siswa adalah $46,90 \%$.

Observasi aktivitas guru serta nilai hasil tes siswa dapat dijadikan sebagai dasar untuk diadakan perbaikan dalam pembelajaran. Aktivitas guru, pada kegiatan pra siklus ini dikatakan sedang karena perolehan persentasi aktivitas pada pra siklus ini mencapai $64,70 \%$ dan nilai yang diperoleh dari hasil tes siswa menunjukan bahwa siswa kelas XI masih banyak yang belum mencapai kriteria ketuntasan minimal belajar. Pada akhir pre tes guru memberikan informasi mengenai pembelajaran yang akan digunakan pada pertemuan berikutnya, yaitu pembelajaran menggunakan metode TTW (Think Talk Write) dan setelah itu guru akan membagi dari 30 siswa menjadi 6 kelompok dengan materi Menganalisis budaya politik di indonesia, kemudian guru menyuruh siswa agar materi tersebut di pelajari di rumah masing-masing.

Pada tindakan siklus pertama kegiatan dilakukan pada tahap perencanaan yang dilaksanakan pada hari sabtu 04 februari
2017. Adapun untuk mendapatkan hasil yang memuaskan maka peneliti dan guru bidang studi perlu persiapan yang sangat maksimal untuk mencapai materi, khusunya pada mata pelajaran Pendidikan kewarganegaan dengan materi Menganalisis budaya politik di indonesia. Pada tahap perencanaan tindakan pertama ini adalah sebagai berikut : 1) Menyusun lembar observasi untuk siswa dalam proses pembelajaran, yang terdiri dari lembar observasi siswa dapat dilihat pada lampiran.

2) Menyusun RPP dengan penggunaan metode TTW (Think Talk Write) pada pelajaran Pendidikan Kewarganegaan, RPP dapat dilihat pada lampiran. 3) Menyusun soal, tes evaluasi berupa tes tertulis.

Pada pelaksanaan tindakan siklus I pada hari Rabu tanggal 08 Februari 2017, pelaksanaan pembelajaran dengan menggunakan metode TTW (Think Talk Write) pada mata pelajaran Pendidikan kewarganegaraan pada bahan ajar Budaya politik, kegiatandilaksanakan selama $2 \times 45$ menit mulai pukul 11.30-13.15 WIB, kegiatan dilaksanakan sesuai dengan RPP.

Pada pelaksanaan tes evaluasi siklus I yaitu pada hari Rabu 15 Februari 2017 dilaksanakan tes putaran siklus I, pemberian tes ini supaya guru mengetahui hasil belajar siswa dan mengetahui kemampuan siswa tentang penguasaan pelajaran Pendidikan kewarganegaan bahan ajar Budaya politik 
dan guru menjelaskan bahwa skor individu diperoleh dari skor tes.

Tabel 2. Instrumen Penilaian Hasil Belajar

Siswa Siklus I Penelitian Tindakan Kelas

\begin{tabular}{|c|c|c|c|c|c|c|c|}
\hline \multirow[t]{2}{*}{ No } & \multirow[t]{2}{*}{ Nama } & \multicolumn{5}{|c|}{ Skor Nilai } & \multirow{2}{*}{ Jumlah Nilai } \\
\hline & & $\mathbf{1}$ & 2 & 3 & 4 & 5 & \\
\hline $\mathbf{I}$ & AF & 1 & 2 & 2 & 2 & 1 & 8 \\
\hline 2 & $\mathrm{AG}$ & 1 & 1 & 2 & 1 & 2 & 7 \\
\hline 3 & $\mathrm{AM}$ & 1 & 2 & 1 & 1 & 2 & 7 \\
\hline 4 & A & 1 & 1 & 2 & 1 & 1 & 6 \\
\hline 5 & CA & 1 & 2 & 1 & 1 & 2 & 7 \\
\hline 6 & CDP & 1 & 1 & 1 & 1 & 2 & 6 \\
\hline 7 & FR & 1 & 2 & 2 & 1 & 3 & 9 \\
\hline 8 & FM & 2 & 2 & 1 & 1 & 3 & 9 \\
\hline 9 & $\mathrm{H}$ & 1 & 2 & 2 & 1 & 3 & 9 \\
\hline 10 & $\mathrm{HB}$ & 2 & 2 & 1 & 1 & 2 & 8 \\
\hline 11 & IS & 1 & 2 & 1 & 1 & 1 & 6 \\
\hline 12 & M.I & 1 & 2 & 2 & 1 & 2 & 8 \\
\hline 13 & MP & 1 & 2 & 2 & 1 & 2 & 8 \\
\hline 14 & MS & 1 & 2 & 2 & 1 & 2 & 8 \\
\hline 15 & MS & 1 & 1 & 1 & 1 & 2 & 6 \\
\hline 16 & M.R & 1 & 2 & 2 & 1 & 2 & 8 \\
\hline 17 & M & 1 & 2 & 2 & 2 & 1 & 8 \\
\hline 18 & M.F & 1 & 2 & 3 & 2 & 1 & 8 \\
\hline 19 & M.A & 1 & 2 & 2 & 2 & 1 & 8 \\
\hline 20 & ND & 2 & 1 & 2 & 1 & 1 & 7 \\
\hline 21 & NN & 2 & 2 & 1 & 2 & 1 & 8 \\
\hline 22 & NND & 1 & 2 & 2 & 2 & 1 & 8 \\
\hline 23 & $\mathrm{RH}$ & 2 & 2 & 2 & 2 & 1 & 9 \\
\hline 24 & RR & 2 & 3 & 2 & 1 & 1 & 9 \\
\hline 25 & SR & 2 & 2 & 2 & 1 & 2 & 9 \\
\hline 26 & SS & 1 & 1 & 1 & 2 & 2 & 7 \\
\hline 27 & SW & 2 & 3 & 1 & 2 & 1 & 9 \\
\hline 28 & TSD & 2 & 2 & 2 & 1 & 2 & 9 \\
\hline 29 & TS & 2 & 2 & 2 & 2 & 1 & 9 \\
\hline 30 & YS & 1 & 2 & 3 & 2 & 1 & 9 \\
\hline \multicolumn{3}{|c|}{$\begin{array}{l}\text { Total } \\
\text { Nilai Rata-Rata }\end{array}$} & & & & & $\begin{array}{c}254 \\
10,16\end{array}$ \\
\hline
\end{tabular}

Rumus:

Nilai Rata-rata $=$ Jumlah nilai akhir hasil siswa

Jumlah Indikator $\mathrm{x}$

Jumlah skor

$$
\begin{aligned}
& =\frac{245}{5 \times 5} \\
& =\frac{245}{25}=10,16
\end{aligned}
$$

Tabel 3. Kriteria hasil belajar siswa

\begin{tabular}{cc}
\hline Kelas & Kategori \\
\hline $\mathbf{1 9}-\mathbf{2 5}$ & Tinggi \\
$\mathbf{1 2}-\mathbf{1 8}$ & Sedang \\
$\mathbf{5 - 1 1}$ & Rendah \\
\hline
\end{tabular}

Keterangan :

- Jika siswa siswa mendapat skor 19 sampai dengan 25 maka indikator hasil belajar siswa pada proses pembelajaran di katakan tinggi.

- Jika siswa mendafatkan skor 12 samapai 18 maka hasil belajar siswa pada proses pembelajaran di katakan sedang.

- Jika siswa mendapatkan skor 5 samapai dengan 11 maka hasil belajar siswa pada proses pembelajaran di katakan rendah.

Refleksi di siklus II merupakan tahap evaluasi dari siklus I karena pada tahap siklus I peneliti dirasa masih kurang dan belum dapat di katakan baik selama proses pelaksanaan tindakan pada siklus I masih banyak kekurangan antara lain:

Pada siklus pertama pembelajaran metode TTW (Think Talk Write) menurut hasil observasi peneliti masih kurang menyentuh pada prinsip- prinsip pembelajaran metode TTW (Think Talk Write), seperti kurang teratur pada saat membuat kelompok, kurang fokus dalam menyampaikan materi kepada temannya, kurang rapi dalam membuat kelompok dan masih ada yang bercanda dalam melaksanakan metode $T T W$ (Think Talk Write).

Perencanaan dilaksanakan hari sabtu 18 Februari 2017, adapun yang dilakukan selama pembelajaran siklus I, hampir sama dengan siklus II. Tetapi pada siklus II dituntut harus benar-benar serius dalam mengerjakan soal yang diberikan oleh 
peneliti, karena pada siklus II merupakan hasil akhir belajar siswa dan akhir pembelajaran siklus II, adapun yang dilakukan persiapan diantara lain sebagai berikut:1) Menyusun rencana pelaksanaan pembelajaran (RPP) tentang materi yang diajarkan dengan penggunaan pembelajaran metode TTW (Think Talk Write) pada mata pelajaran Pendidikan kewarganegaan, RPP dapat dilihat pada lampiran.2) Membuat lembar kerja siswa dapat dilihat dalam lampiran. 3) Menyusun soal tes evaluasi siklus II.

Pelaksanaan tindakan pada siklus II dilaksanakan selama 2 kali pertemuan yaitu pada hari Rabu 22 februari 2017 pelaksanaan pembelajaran dan 25 Februari 2017 melakukan pengamatan dan evaluasi, materi yang dipelajari sesuai dengan rencana pelaksanaan pembelajaran (RPP).

Pertemuan pertama pada siklus II dilaksanakan Rabu 22 Februari 2017, dimulai pukul 11.30-13.15 WIB. Pada awal pembelajaran guru mengevaluasi materi sebelumnya dan mengingatkan dengan tanya jawab tentang materi sebelumnya. Guru memberikan motivasi dan berpartisipasi aktif selama pembelajaran berlangsung.

Pelaksanaan siklus II ini guru memfokuskan terhadap siswa yang belum tuntas belajar dengan cara membimbing siswa supaya dengan penyampaian pelajaran pendidikan kewarganegaan dengan pokok bahasan budaya politik.

Pelaksanaan tes evaluasi siklus II dilaksanakan pada hari Rabu tanggal 1 Maret 2017, dengan materi Budaya politik. Tes dilaksanakan pada pukul 11.30-13.15 WIB tes ini dilaksanakan dengan cara tes tertulis dan siswa sangat serius dalam mengerjakan soal tes, karena peneliti dan guru bidang studi benar-benar mengontrol siswa dnegan teliti dan ini merupakan siklus terakhir karena peneliti menggunakan 2 siklus. Berdasarkan perolehan data dapat dilihat bahwa ada peningkatan nilai dari siklus I ke siklus II, dari tes evaluasi siklus II terdapat 27 siswa yang sudah mencapai ketuntasan belajar dan 3 orang siswa yang belum mencapai kriteria ketuntasan minimal. Berarti untuk tingkat ketuntasan meningkat dari siklus sebelumnya, rata-rat nilai 30 siswa adalah $80,23 \%$. Hasil observasi aktivitas guru pada siklus II dapat dilihat bahwa aktivitas guru pada siklus II sudah mengalami peningkatan dari skor nilai yang diperoleh $63(74,11 \%)$ pada siklus I menjadi 71 $(83,52 \%)$ pada siklus II, hal ini terjadi karena pemahaman yang baik antara guru dan siswa tentang metode TTW (Think Talk Write), sehingga guru dan siswa aktif secara bersama-sama dalam proses pembelajaran Pendidikan kewarganegaan materi Budaya politik. 
Tabel 4. Instrumen Penilaian Hasil Belajar

Siswa Siklus II Penelitian Tindakan Kelas

\begin{tabular}{|c|c|c|c|c|}
\hline No & Nama & Skor Nila: & & Jumlah Skor \\
\hline 1 & $\overline{\mathrm{AF}}$ & 5554 & 5 & 25 \\
\hline 2 & $\mathrm{AG}$ & 5554 & 5 & 25 \\
\hline 3 & $\mathrm{AM}$ & 4554 & 5 & 23 \\
\hline 4 & A & 4555 & 5 & 24 \\
\hline 5 & $\mathrm{CA}$ & 5543 & 5 & 24 \\
\hline 6 & CDP & 4543 & 5 & 23 \\
\hline 7 & FR & 5554 & 5 & 24 \\
\hline 8 & FM & 5555 & 4 & 24 \\
\hline 9 & $\mathrm{H}$ & 5554 & 5 & 24 \\
\hline 10 & $\mathrm{HB}$ & 5544 & 5 & 23 \\
\hline 11 & IS & 5555 & 4 & 24 \\
\hline 12 & M.I & 4455 & 5 & 23 \\
\hline 13 & MP & 5555 & 5 & 25 \\
\hline 14 & MS & 4445 & 5 & 22 \\
\hline 15 & MS & 5555 & 4 & 24 \\
\hline 16 & M.R & 4455 & 5 & 23 \\
\hline 17 & M & 5554 & 5 & 24 \\
\hline 18 & M.F & 4455 & 4 & 22 \\
\hline 19 & M.A & 5554 & 4 & 23 \\
\hline 20 & $\mathrm{ND}$ & 5555 & 4 & 24 \\
\hline 21 & NN & 4555 & 4 & 23 \\
\hline 22 & NND & 5555 & 5 & 25 \\
\hline 23 & $\mathrm{RH}$ & 4454 & 5 & 22 \\
\hline 24 & $R R$ & 5544 & 5 & 23 \\
\hline 25 & SR & 4545 & 5 & 23 \\
\hline 26 & SS & 4455 & 5 & 23 \\
\hline 27 & SW & 5555 & 4 & 24 \\
\hline 28 & TSD & 4455 & 5 & 23 \\
\hline 29 & TS & 5455 & 5 & 24 \\
\hline \multirow[t]{2}{*}{30} & YS & 5554 & . & 23 \\
\hline & Total & & & 706 \\
\hline \multicolumn{2}{|c|}{ Nilai Rata-rata } & & & 28,24 \\
\hline
\end{tabular}

Rumus:

Nilai Rata-rata $=$ Jumlah nilai akhir hasil siswa

Jumlah Indikator x Jumlah skor

$$
\begin{aligned}
= & \frac{706}{5 \times 5} \\
= & \frac{706}{25}=28,24
\end{aligned}
$$

Tabel 5. Kriteria hasil belajar siswa

\begin{tabular}{cc}
\hline Kelas & Kategori \\
\hline $\mathbf{1 9}-\mathbf{2 5}$ & Tinggi \\
$\mathbf{1 2}-\mathbf{1 8}$ & Sedang \\
$\mathbf{5}-\mathbf{1 1}$ & Rendah \\
\hline
\end{tabular}

Keterangan :

- Jika siswa siswa mendapat skor 19 sampai dengan 25 maka indikator hasil belajar siswa pada proses pembelajaran di katakan tinggi.

- Jika siswa mendafatkan skor 12 samapai 18 maka hasil belajar siswa pada proses pembelajaran di katakan sedang.

- Jika siswa mendapatkan skor 5 samapai dengan 11 maka hasil belajar siswa pada proses pembelajaran di katakan rendah.

$$
\text { Refleksi dilakukan untuk }
$$

mengevaluasi pembelajaran siklus II, dari kegiatan refleksi ternyata siswa memahami materi dengan menggunakan metode TTW (Think Talk Write) pada mata pelajaran Pendidikan kewarganegaan, khusunya pada bahan ajar Budaya politik.

Berdasarkan hasil penelitian diatas, menunjukan bahwa ada peningkatan hasil belajar siswa pada mata pelajaran Pendidikan kewarganegaan bahan ajar Budaya politik. Hal ini menunjukan bahwa hasil belajar siswa dengan menggunakan metode pembelajaran TTW (Think Talk Write) meningkatkan hasil belajar siswa dalam belajar.

Dari observasi yang dilakukan dalam dua siklus diperoleh dua kesimpulan bahwa 
aktivitas dan kemampuan siswa dalam mengikuti pembelajaran Pendidikan kewarganegaan dengan menggunakan metode TTW (Think Talk Write) berlangsung dengan efektif dan mengalami peningkatan dari 47,62\% yang mencapai KKM pada siklus I menjadi $90,48 \%$ pada siklus II. Dari hasil observasi juga diperoleh kesimpulan bahwa skor rata-rat meningkat dari $68,57(68,57 \%)$ pada siklus I menjadi $80,23(80,23 \%)$ pada siklus II beberapa keunggulan metode ini adalah :

1. Siswa menyukai metode $T T W$ (Think Talk Write) karena selaras dengan karakter anak yang menyukai suatu hal yang baru.

2. Metode TTW (Think Talk Write) melatih daya ingat hasil belajar siswa serta meningkatkan keaktifan belajar peserta didik.

3. Siswa berlomba-lomba memahami materi untuk membagikan informasi kepada temannya.

Dari hasil observasi yang dilakukan dalm dua siklus diperoleh kesimpulan bahwa aktivitas guru meningkat dari $74,11 \%$ pada siklus I menjadi 90,48\% pada siklus II. Peningkatan ini disebabkan oleh beberapa faktor, antara lain:

1. Pemahaman guru terhadap metode TTW (Think Talk Write) semakin meningkat.

2. Respon dan antusian siswa terhadap pembelajaran

pendidikan

kewarganegaan

dengan

menggunakan metode TTW (Think

Talk Write) ini sangat bagus.

3. Penggunaan metode TTW (Think Talk Write) ini menunjukan keefektivan terhadap kemampuan belajar siswa.

Dari hasil observasi yang dilakukan ada beberapa faktor yang menghambat proses pembelajaran pendidikan kewarganegaraan dengan menggunakan metode TTW (Think Talk Write) faktor-faktor itu antara lain:

1. Waktu yang tersedia untuk pembelajaran Pendidikan

Kewarganegaan terbatas yaitu $2 \times 45$ menit dalam seminggu, sedangkan waktu yang ideal yang dibutuhkan adalah 5 sampai 10 jam perminggu.

2. Kemampuan siswa yang bervariatif, serta kesadaran orang tua siswa dalam membimbing siswa belajar di rumah.

3. Ketidakhadiran siswa dalam proses pembelajaran mempengaruhi hasil belajar

Diagram 1. Nilai Perbaikan Pembelajaran Siswa Kelas XI MA Masyariqul Anwar Caringin Pra Siklus, Siklus I, dan Siklus II

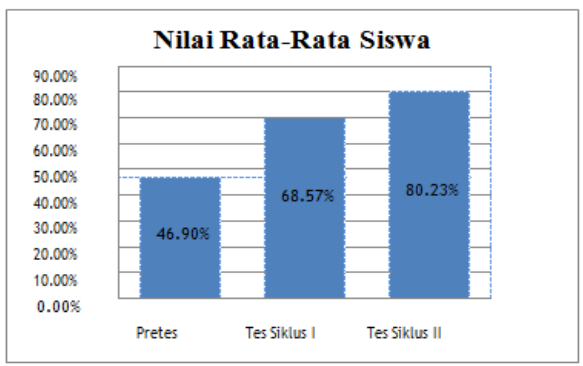


Tabel 6 Presentasi Ketuntasan Belajar Siswa Dari Setiap Tes

\begin{tabular}{ccll}
\hline $\begin{array}{l}\text { Hasil Untuk } \\
\text { Skor Tes }\end{array}$ & KKM & $\begin{array}{l}\text { Rata- } \\
\text { Rata } \\
\text { Skor } \\
\text { Tes }\end{array}$ & $\begin{array}{l}\text { Presentasi } \\
\text { Ketuntasan }\end{array}$ \\
\hline \multicolumn{1}{c}{ Pretes } & 70 & 46,90 & $\mathbf{4 , 7 7 \%}$ \\
Tes Siklus I & 70 & 68,57 & $\mathbf{4 7 , 6 2 \%}$ \\
Tes Siklus II & 70 & 80,23 & $90,48 \%$ \\
\hline
\end{tabular}

Pada setiap siklus guru penelitian sudah berusaha dalam pembelajaran menggunakan metode TTW (Think Talk Write), pada siklus I pembelajaran lebih difokuskan untuk meningkatkan siswa dalam belajar menggunakan tes perindividu dan siswa dituntut lebih belajar mandiri, siswa juga terlihat berinteraksi bersama guru maupun antara siswa siklus II merupakan pemantapan tindakan siklus I. Penggunaan lembar kerja dalam proses pembelajaran bertujuan untuk mempermudah siswa dalam memahami materi dengan menggunakan metode $T T W$ (Think Talk Write) pada mata pelajaran Pendidikan kewarganegaraan bahan ajar Budaya politik. Pada hari yang ditentukan oleh peneliti, setiap siswa mengerjakan tes secara individu.

\section{KESIMPULAN}

Berdasarkan hasil penelitian tindakan kelas yang dilaksanakan di kelas XI IPS 1 MA Masyariqul Anwar Caringin Kab. Pandeglang, maka penulis mengambil kesimpulan bahwa:
1. Dalam perencanaan penerapan model pembelajaran Think Talk Write pada mata pelajaran (PKn) untuk meningkatkan hasil belajar siswa. Peneliti melakukan analisis standar isi untuk mengetahui Standar Kopetensi dan Kopetensi Dasar ( SK dan KD )

2. Pada pelaksanaan penerapan model pembelajaran Think Talk Write dalam mata pelajaran pendidikan kewarganegaraan bahan ajar Budaya politik, kegiatan di laksanakan selama 2x45 menit di kelas XI IPS 1 MA Masyariqul anwar caringin

3. Dalam penerapan model pembelajaran Think Talk Write ada beberapa faktor hambatan: Kemampuan siswa yang bervariatif, serta kesadaran orang tua siswa dalam membimbing siswa belajar di rumah.Ketidakhadiran siswa dalam proses pembelajaran mempengaruhi hasil belajar.

4. Pembelajaran dengan menggunakan model pembelajaran Think Talk Write pada mata pelajaran pendidikan kewarganegraan berjalan baik. Hal ini terlihat dari kenaikan nilai rata-rata evaluasi yang mengalami peningkatan dalam tiap siklus yang telah mencapai nilai KKM. Pada pelaksanaan pre-test dengan perolehan nilai belajar siswa yaitu rata-rata sebesar 46,90. Dengan jumlah siswa yang tuntas mencapai nilai 
KKM sebanyak 11 orang siswa, dan yang belum tuntas mencapai nilai KKM sebanyak 19 orang siswa. Kemudian evaluasi pada siklus I diperoleh nilai rata-rata yaitu sebesar 68,57, dengan 13 orang siswa yang tuntas mencapai nilai KKM dan 17 siswa yang belum tuntas mencapai nilai KKM. Siklus II nilai ratarata diperoleh sebesar 80,23, dengan 26 orang siswa yang tuntas mencapai nilai KKM dan 4 orang siswa yang belum tuntas mencapai nilai KKM.

\section{DAFTAR PUSTAKA}

\section{a. Buku}

Abdullah Sani, Ridwan. 2013. Inovasi Pembelajaran. Jakarta: Bumi Aksara.

Hamalik, Oemar. 2002. Psikologi Belajar Mengajar. Bandung: Sinar Baru Al gesindo

Huinker, D \& Laughlin, C. 1996. Talk your way into writing. Dalam Portia C Elliott \& Margaret J. Kenney (Eds). Communication in Mathematics, K-12 and beyond. Reston, Va: National Council of Teacher of Mathematics.

Slameto. 2003. Belajar dan Faktor-aktor yang Mempengaruhinya. Jakarta: Rineka Cipta

\section{b. Perundang-undangan}

Undang-Undang Republik Indonesia No. 20 Tahun 2003 tentang Sistem Pendidikan Nasional 